\title{
Papers
}

\section{Cancer after pre-eclampsia: follow up of the Jerusalem perinatal study cohort}

Ora Paltiel, Yehiel Friedlander, Efrat Tiram, Micha Barchana, Xiaonan Xue, Susan Harlap

\begin{abstract}
Objective To compare the incidence of cancer among women with and without a history of pre-eclampsia.

Design Cohort study.

Setting Jerusalem perinatal study of women who delivered in three large hospitals in West Jerusalem during 1964-76.

Participants 37033 women.

Main outcome measures Age adjusted and multivariable adjusted hazard ratios for cancer incidence for the entire cohort and for women who were primiparous at study entry.

Results Cancer developed in 91 women who had pre-eclampsia and 2204 who did not (hazard ratio 1.27, 95\% confidence interval 1.03 to 1.57 ). The risk of site specific cancers was increased, particularly of the stomach, ovary epithelium, breast, and lung or larynx. The incidence of cancer of the stomach, breast, ovary, kidney, and lung or larynx was increased in primiparous women at study entry who had a history pre-eclampsia.

Conclusions A history of pre-eclampsia is associated with increases in overall risk of cancer and incidence at several sites. This may be explained by environmental and genetic factors common to the development of pre-eclampsia and cancer in this population.
\end{abstract}

\section{Introduction}

Pre-eclampsia, a common complication of pregnancy, is an important cause of short term morbidity and mortality in fetuses and mothers. Risk factors for this condition include nulliparity, previous hypertension, and high maternal weight. ${ }^{1}$ Preeclampsia has been associated with increased long term mortality for mothers, mainly from cardiovascular causes. ${ }^{2}$

The risk of cancer and risk of death from cancer have been inconsistently associated with pre-eclampsia (see table 1). A cohort study based on the Norwegian birth registry showed a relative hazard of 0.36 for cancer specific mortality among mothers who had had pre-eclampsia between the 16th and 36th week of pregnancy, but the $95 \%$ confidence interval was wide (0.12 to 1.11$){ }^{2}$ Another cohort study, based on the Swedish cancer registry, showed no association between pre-eclampsia and cancer of the cervix, endometrium, ovary, or breast. ${ }^{3}$ A recent cohort study comparing women with and without a history of pre-eclampsia showed a non-significantly decreased rate ratio for breast cancer; however, pregnancy associated hypertension and specific placental abnormalities were significantly and independently associated with a decreased risk. ${ }^{4}$ Furthermore, a large cohort study comparing women with pre-eclampsia or hypertension in their first pregnancy compared with those with- out showed a significant reduction in risk of breast cancer (rate ratio $0.81,95 \%$ confidence interval 0.71 to 0.91$).^{5}$ Three case-control studies found a protective effect of pre-eclampsia on breast cancer with odds ratios ranging from 0.27 to 0.81 ; one of these, however, was based on only two cases of cancer among women with pre-eclampsia. ${ }^{6-8}$ Another was based on a history of hypertension late in pregnancy rather than pre-eclampsia in itself. ${ }^{7}$ Several studies have found that maternal pre-eclampsia reduces the risk of breast cancer up to fourfold in female offspring. ${ }^{9}$ We investigated overall cancer incidence as well as incidence at specific sites in women in the Jerusalem perinatal study cohort.

\section{Methods}

The Jerusalem perinatal study cohort (92408 offspring of 44067 mothers) comprises all births in 1964-76 to residents of West Jerusalem. It was originally planned as a survey of pre-eclampsia, the condition being defined then as a systolic blood pressure of $\geq 140 \mathrm{~mm} \mathrm{Hg}$ or a diastolic blood pressure or $\geq 90 \mathrm{~mm} \mathrm{Hg}$, or both, together with a proteinuria and oedema. (The currently accepted definition of pre-eclampsia does not include oedema $\left.{ }^{10}\right)$. Baseline data were recorded by the study staff at the time of birth. ${ }^{11}$ In 2000 we traced 40455 (91.8\%) of the mothers through the Israel population registry using the unique identity number assigned to all Israeli residents. The $8.2 \%$ who remained untraced included a high proportion of foreign nationals and temporary residents. We obtained information on vital status for 39809 (98.4\%) of the traced mothers, the remainder $(1.6 \%)$ being unavailable for follow up because of emigration or assignment of new identity numbers.

Mothers were linked by way of their identity number to the Israel Cancer Registry, which was set up in 1961. Reporting of cases of cancer has been obligatory by law since 1981, but even before this reporting was considered relatively complete. ${ }^{12}$ Quality control surveys are undertaken periodically, the last in 1993, indicating that records of breast cancer are $94.2 \%$ complete and records of ovarian cancer are $95.8 \%$ complete. ${ }^{13}$

\section{Statistical methods}

We compared the distribution of baseline characteristics as well as the risk of cancer in women with pre-eclampsia recorded at any birth in the cohort (1964-76) with those without pre-eclampsia. After studying the data using life table methods, we used bivariate and multivariate Cox proportional hazards models to assess the risk of cancers at all sites and at specific sites. We adjusted for age and for other factors associated with pre-eclampsia and cancers at specific sites. Age at entry to the cohort was introduced into the models as a continuous variable. 
Table 1 Review of studies reporting risk of cancer after pre-eclampsia

\begin{tabular}{|c|c|c|c|c|c|c|c|c|c|}
\hline \multirow[b]{2}{*}{ Study } & \multirow[b]{2}{*}{$\begin{array}{l}\text { Country, } \\
\text { population }\end{array}$} & \multirow[b]{2}{*}{ Design } & \multirow[b]{2}{*}{$\begin{array}{l}\text { Definition of } \\
\text { exposure }\end{array}$} & \multirow{2}{*}{$\begin{array}{l}\text { Cancer cases } \\
\text { with or without } \\
\text { pre-eclampsia }\end{array}$} & \multicolumn{5}{|c|}{ Results } \\
\hline & & & & & Cancer mortality & $\begin{array}{l}\text { Overall cancer } \\
\text { incidence }\end{array}$ & $\begin{array}{l}\text { Breast cancer } \\
\text { incidence }\end{array}$ & $\begin{array}{l}\text { Other specific } \\
\text { sites }\end{array}$ & Comments \\
\hline $\begin{array}{c}\text { Polednak } \\
1983^{6}\end{array}$ & $\begin{array}{c}\text { USA, } \\
<45 \text { years old }\end{array}$ & Case-control & $\begin{array}{c}\text { Toxaemia or } \\
\text { pre-eclampsia in first } \\
\text { pregnancy }\end{array}$ & $2 / 15$ & NR & $N R$ & $\begin{array}{l}\text { Odds ratio } 0.27 \\
(0.08 \text { to } 0.63) \dagger\end{array}$ & $\mathrm{NR}$ & \\
\hline $\begin{array}{c}\text { Thompson } \\
1989^{7}\end{array}$ & $\begin{array}{c}\text { USA, } \\
\text { 20-54 years old }\end{array}$ & Case-control & $\begin{array}{c}\text { Hypertension } \\
\text { diagnosed before end } \\
\text { of most recent term } \\
\text { pregnancy }\end{array}$ & 139/196 & NR & NR & $\begin{array}{l}\text { Odds ratio } 0.73 \\
(0.59 \text { to } 0.92)^{*}\end{array}$ & NR & \\
\hline Troisi $1998^{8}$ & $\begin{array}{c}\text { USA, } \\
\text { 20-44 years old }\end{array}$ & Case-control & $\begin{array}{c}\text { Toxaemia ever; } \\
\text { toxaemia in first } \\
\text { pregnancy }\end{array}$ & $97 / 121 ; 54 / 66$ & $N R ; N R$ & $N R ; N R$ & $\begin{array}{l}\text { Odds ratio } 0.81 \\
(0.61 \text { to } 1.1)^{\star} ; \\
\text { odds ratio } 0.81 \\
(0.56 \text { to } 1.2)^{\star}\end{array}$ & NR; NR & $\begin{array}{l}\text { Adjusted for age, site, } \\
\text { race, parity, body mass } \\
\text { index, menopausal } \\
\text { status }\end{array}$ \\
\hline Mogren $2001^{3}$ & $\begin{array}{l}\text { Sweden, Swedish } \\
\text { cancer registry }\end{array}$ & Cohort & $\begin{array}{l}\text { Pre-eclampsia (ICD-8 } \\
\text { and ICD-9) }\end{array}$ & $\mathrm{NR}$ & NR & NR & No association & $\begin{array}{l}\text { No association } \\
\text { with cervix or } \\
\text { endometrial } \\
\text { cancer }\end{array}$ & \\
\hline Cohn $2001^{4}$ & $\begin{array}{l}\text { USA, white } \\
\text { non-Hispanic }\end{array}$ & Cohort & $\begin{array}{l}\text { Pre-eclampsia in first } \\
\text { pregnancy; increase } \\
\text { in systolic blood } \\
\text { pressure between } \\
\text { second and third } \\
\text { trimester }\end{array}$ & 2/141; NR & NR; NR & NR; NR & $\begin{array}{l}\text { Rate ratio } 0.6 \\
(0.17 \text { to } 2.09)^{*} \\
\text { rate ratio } 0.5 \\
(0.31 \text { to } 0.82)^{*}\end{array}$ & NR; NR & $\begin{array}{l}\text { Highest quartile of } \\
\text { blood pressure change } \\
\text { compared with no } \\
\text { change; adjusted for } \\
\text { age, parity, and weight }\end{array}$ \\
\hline Irgens $2001^{2}$ & $\begin{array}{l}\text { Norway, } \\
\text { Norwegian birth } \\
\text { registry }\end{array}$ & Cohort & $\begin{array}{c}\text { Pre-eclampsia at }>37 \\
\text { weeks; pre-eclampsia } \\
\text { at } 16-36 \text { weeks }\end{array}$ & NR; NR & $\begin{array}{c}0.9 \\
(0.29 \text { to } 2.78)^{\star} \\
0.36 \\
(0.12 \text { to } 1.11)^{\star}\end{array}$ & $N R ; N R$ & NR; NR & NR; NR & \\
\hline Vatten $2002^{5}$ & $\begin{array}{c}\text { Norway, } \\
\text { Norwegian } \\
\text { cancer registry }\end{array}$ & Cohort & $\begin{array}{l}\text { Pre-eclampsia or } \\
\text { hypertension in first } \\
\text { pregnancy, or both }\end{array}$ & $280 / 5194$ & $\mathrm{NR}$ & NR & $\begin{array}{l}\text { Rate ratio } 0.81 \\
(0.71 \text { to } 0.91)^{*}\end{array}$ & NR & $\begin{array}{l}\text { Adjusted for age, } \\
\text { calendar period, age at } \\
\text { first birth, parity }\end{array}$ \\
\hline Current study & $\begin{array}{l}\text { Israel, Jerusalem } \\
\text { perinatal study }\end{array}$ & Cohort & $\begin{array}{l}\text { Pre-eclampsia in any } \\
\text { pregnancy }\end{array}$ & $91 / 2204$ & NR & $\begin{array}{l}\text { Hazard ratio } 1.27 \\
(1.03 \text { to } 1.57)^{*}\end{array}$ & $\begin{array}{l}\text { Hazard ratio } 1.38 \\
(1.0 \text { to } 1.89)^{*}\end{array}$ & $\begin{array}{l}\text { Increased hazard } \\
\text { ratio for } \\
\text { stomach, lung or } \\
\text { larynx, and } \\
\text { ovarian }\end{array}$ & $\begin{array}{l}\text { All hazard ratios } \\
\text { adjusted for age; breast } \\
\text { cancer hazard ratio } \\
\text { adjusted for parity as } \\
\text { well }\end{array}$ \\
\hline
\end{tabular}

$\mathrm{NR}=$ not reported

${ }^{*} 95 \%$ confidence interval.

$\dagger 90 \%$ confidence interval.

When assessing risk of breast cancer for all mothers, we adjusted for parity and age simultaneously. Age at entry corresponded to age at first birth for the 22716 primiparous mothers at study entry. Other variables tested were social class (by husband's occupation), years of education, ethnic origin (west Asia (Iraq, Iran, Kurdistan, Yemen, India, Afghanistan, Turkey, Syria, Lebanon), north Africa (mainly Morocco), Europe or the Americas and other Western countries, or Israeli born), immigration, religion, insulin dependent diabetes mellitus, gestational diabetes, birth weight, and birth defects of the offspring. Follow up was from the first observed birth in the cohort to diagnosis of cancer, death, or 30 June 1999. We excluded women whose diagnosis predated entry into the cohort. The analysis was restricted to the $92 \%$ of women delivering in the three largest hospitals in West Jerusalem, in which recording of obstetric complications was deemed to be complete. A priori we also studied the subgroup observed from their first birth. For cancers at specific sites, we restricted the analyses to the 17 sites with at least 25 cases. We report hazard ratios, $95 \%$ confidence intervals, and two sided $\mathrm{P}$ values.

\section{Results}

The analysis included 37033 women, of whom 99\% were Jewish and 99\% were married. Pre-eclampsia was recorded in 1070 $(2.9 \%)$. Table 2 shows the baseline characteristics of women with and without pre-eclampsia. Pre-eclamptic women were older at baseline. Entry to the study cohort was at the first completed pregnancy for $57.8 \%$ for women with and $61.5 \%$ of women without pre-eclampsia. Ethnicity of west Asian origin was more com- mon among women with pre-eclampsia (31.4\%) than those without $(28.6 \%)$. Women with pre-eclampsia were more likely to be of lower social class than those without. Fifty six (5.2\%) women with pre-eclampsia had gestational diabetes compared with 349 $(1.0 \%)$ women without. The median length of follow up was 29 years.

In total, 2295 first primary cancers were reported, including $978(42.6 \%)$ of the breast. After pre-eclampsia there was an overall excess of cancer when all sites were combined (age adjusted hazard ratio $1.27,95 \%$ confidence interval 1.03 to 1.57 ). The risk of breast cancer was significantly increased for pre-eclamptic women after adjusting for age and parity $(1.38,1.0$ to 1.89$)$. The risk of cancers of the stomach, ovary epithelium, and lung or larynx were statistically significantly increased after adjustment for age (table 3). Multivariable adjustment did not substantially change the hazard ratios.

In the 22716 women followed from their first birth there were increases in age adjusted risk of all cancers $(1.58,1.20$ to $2.07)$ and cancers of the stomach $(6.45,2.16$ to 19.3$)$, breast $(1.75$, 1.19 to 2.58$)$, ovary $(3.25,1.15$ to 9.19$)$, kidney $(4.83,1.07$ to 21.9$)$, and lung or larynx $(2.87,0.67$ to 12.3$)$.

We compared the personal characteristics and outcome of cancer in 2766 women who were excluded from the analysis because they did not deliver in the study hospitals. These women were older at their first birth (mean age 27.3 years for excluded women versus 26.2 for included women) and were more likely to be non-Jewish $(6.3 \% v 1.0 \%)$ or of European origin $(47.2 \% v$ $34.7 \%)$. Cancer occurred in $194(7.1 \%)$, of which $88(45 \%)$ had breast cancer compared with $42.6 \%$ in the included cohort. Only 10 women in the excluded group had pre-eclampsia recorded, 
Table 2 Distribution of baseline characteristics of women with and without pre-eclampsia

\begin{tabular}{|c|c|c|}
\hline Variable & $\begin{array}{c}\text { No (\%) without } \\
\text { pre-eclampsia (n=35 963) }\end{array}$ & $\begin{array}{c}\text { No }(\%) \text { with } \\
\text { pre-eclampsia ( } \mathrm{n}=1070)\end{array}$ \\
\hline \multicolumn{3}{|c|}{ Age (years) at baseline: } \\
\hline$<20$ & $2517(7.0)$ & $54 \quad(5.1)$ \\
\hline $20-24$ & 14361 (39.9) & $382(35.7)$ \\
\hline $25-29$ & $10078(28.0)$ & $253(23.6)$ \\
\hline $30-34$ & $5284(14.7)$ & $193(18.0)$ \\
\hline $35-39$ & $2792(7.8)$ & $116(10.8)$ \\
\hline$\geq 40$ & $883(2.5)$ & $70(6.5)$ \\
\hline Unknown & $48 \quad(0.13)$ & $2(0.19)$ \\
\hline \multicolumn{3}{|l|}{ Parity at baseline: } \\
\hline 1 & $22098(61.5)$ & $618(57.8)$ \\
\hline 2 & $4347(12.1)$ & $101(9.4)$ \\
\hline 3 & $3490(9.7)$ & $79(7.4)$ \\
\hline 4 & $1950(5.4)$ & $62(5.8)$ \\
\hline 5 or 6 & $2073(5.8)$ & $83(7.8)$ \\
\hline $7-9$ & $1430(4.0)$ & $88(8.2)$ \\
\hline$\geq 10$ & $519(1.4)$ & $36(3.4)$ \\
\hline Unknown & $56(0.16)$ & $3(0.28)$ \\
\hline \multicolumn{3}{|l|}{ Gestational diabetes: } \\
\hline No & $35614(99.0)$ & 1014 (94.8) \\
\hline Yes & $349(0.97)$ & $56 \quad(5.2)$ \\
\hline \multicolumn{3}{|l|}{ Birthplace of woman: } \\
\hline Israel & $16651(46.3)$ & $450(42.1)$ \\
\hline Other & $19312(53.7)$ & $620(57.9)$ \\
\hline \multicolumn{3}{|c|}{ Birthplace of woman's father: } \\
\hline Israel & $5322(14.9)$ & $149(13.9)$ \\
\hline Other west Asia* & 10301 (28.6) & $336(31.4)$ \\
\hline North Africa & $7845(21.8)$ & $226(21.1)$ \\
\hline Europe, Americas $\dagger$ & $12495(34.7)$ & $359(33.6)$ \\
\hline \multicolumn{3}{|l|}{ Years of education: } \\
\hline $0-8$ & $10726(29.8)$ & $330(30.8)$ \\
\hline $9-12$ & $12953(36.0)$ & $350(32.7)$ \\
\hline$\geq 13$ & $10715(29.8)$ & $333(31.1)$ \\
\hline Unknown & $1569(4.4)$ & $331(31.0)$ \\
\hline \multicolumn{3}{|l|}{ Social classł: } \\
\hline 1-2 (high) & $12875(35.8)$ & $357(33.4)$ \\
\hline $3-4$ & $13972(38.9)$ & $381(35.6)$ \\
\hline 5-6 (low) & $9116(25.4)$ & $332(31.0)$ \\
\hline
\end{tabular}

whereas 80 (95\% confidence interval 63 to 96$)$ would have been expected given the rate in the entire cohort (2.9\%). This indicates systematic underascertainment of pre-eclampsia in this group. Had we included these women in the analysis the age adjusted hazards ratios for cancer at all sites and breast cancer after adjustment for age and parity would have been similar (1.26, 1.02 to 1.55 and $1.39,1.01$ to 1.90 , respectively) to those recorded, in which the analysis was restricted to women who delivered in the three major hospitals where pre-eclampsia was sytematically ascertained.

\section{Discussion}

In contrast to others (see table 1), we found an increased overall incidence of cancer and site specific increases in cancer of the stomach, ovary, and breast after pre-eclampsia, which was especially noticeable in women followed from their first pregnancy. Results for ovarian and breast cancer were not explained by parity, diabetes, ethnic origin, or social variables. Some, but not all, previous studies have found a protective effect of pre-eclampsia on breast cancer. This has been attributed mainly to decreased oestrogen levels, although recent studies have found that progesterone and androgen levels, rather than oestrogen levels, distinguish women with pre-eclampsia from controls. ${ }^{914} 15$ Previous studies on pre-eclampsia have been carried out mainly in northern European or North American populations, as have the studies reporting a protective effect on risk of breast cancer. ${ }^{5-8} 16$

The longer follow up in our study may have brought to light associations not previously observed. ${ }^{6}{ }^{8}$ Furthermore, our analysis was restricted to those with and without criteria for pre-eclampsia and did not include all hypertensive diseases of pregnancy, which were coded separately in the database of the Jerusalem perinatal study. This contrasts with other studies that combined the two or studied hypertension in pregnancy. ${ }^{5} \mathrm{We}$ minimised the possibility of biases in selection and ascertainment by relying on a population based cohort with near complete follow up. Obstetrical care for residents of Israel was universally accessible and without charge throughout the study period. The possibility of differential reporting of cancer or ascertainment of cancer in the Israel Cancer Registry according

Table 3 Incidence of invasive cancers by site and pre-eclampsia status (sites with at least 25 cases)

No of cases

\begin{tabular}{|c|c|c|c|c|}
\hline \multirow[b]{2}{*}{ Cancer site } & & \multirow[b]{2}{*}{ Age adjusted hazard ratio $(95 \% \mathrm{Cl})$} & \multirow[b]{2}{*}{$P$ value } \\
\hline & No pre-eclampsia ( $\mathrm{n}=35$ 963) & After pre-eclampsia $(\mathrm{n}=1070)$ & & \\
\hline Stomach & 46 & 5 & $3.10(1.23$ to 7.84$)$ & 0.017 \\
\hline Colon & 140 & 7 & 1.46 (0.68 to 3.12$)$ & 0.333 \\
\hline Rectum & 68 & 2 & 0.86 (0.21 to 3.53$)$ & 0.839 \\
\hline Pancreas & 27 & 2 & 2.06 (0.49 to 8.70$)$ & 0.326 \\
\hline Lung or larynx & 53 & 5 & 2.81 (1.12 to 7.05$)$ & 0.028 \\
\hline Melanoma & 126 & 5 & 1.28 (0.52 to 3.14$)$ & 0.584 \\
\hline Breast $^{\star}$ & 938 & 40 & 1.38 (1.0 to 1.89$)$ & 0.046 \\
\hline Cervix & 62 & 0 & - & - \\
\hline Endometrium & 70 & 1 & 0.44 (0.06 to 3.18$)$ & 0.417 \\
\hline Ovary epithelium & 79 & 6 & 2.32 (1.01 to 5.34$)$ & 0.047 \\
\hline Bladder & 24 & 1 & 1.20 (0.16 to 8.93$)$ & 0.856 \\
\hline Kidney & 36 & 2 & 1.52 (0.36 to 6.32$)$ & 0.568 \\
\hline Brain or nervous system & 30 & 1 & 0.94 (0.12 to 6.94$)$ & 0.954 \\
\hline Thyroid & 114 & 3 & 0.87 (0.28 to 2.75$)$ & 0.818 \\
\hline Hodgkin's disease & 24 & 1 & $1.41(0.19$ to 10.43$)$ & 0.736 \\
\hline Non-Hodgkin's lymphoma & 90 & 3 & 1.08 (0.34 to 3.41$)$ & 0.898 \\
\hline Leukaemias & 32 & 0 & - & - \\
\hline All others & 245 & 7 & 0.86 (0.40 to 1.82$)$ & 0.689 \\
\hline Total & 2204 & 91 & 1.27 (1.03 to 1.57$)$ & 0.024 \\
\hline
\end{tabular}

${ }^{*}$ Adjusted for age and parity. 


\section{What is already known on this topic}

Some studies have suggested a protective effect of pre-eclampsia on risk of cancer

Few population based studies have been performed

Most have been conducted among northern European or North American populations

\section{What this study adds}

Women with a history of pre-eclampsia are at increased risk of cancer, particularly cancers of the stomach, breast, ovary, and lung and larynx

Specific environmental and genetic factors may contribute to the development of both pre-eclampsia and cancer in Middle Eastern populations

to a previous history of pre-eclampsia is unlikely given the Israeli healthcare system. Recall bias cannot have played a part because pre-eclampsia was diagnosed and recorded at the time of delivery.

We adjusted for age and major risk factors for breast and ovarian cancers; however, we cannot rule out residual confounding. It may be difficult to extrapolate our findings to contemporary parturient women since the current definition of pre-eclampsia no longer includes oedema. Other limitations are the lack of data on the cohort before 1964 and after 1976, which would lead to an underestimate of pre-eclampsia in the cohort, especially among primiparous women at study entry. The possibility remains that some results may be chance findings, as the number of cancers at specific sites is small. Further follow up of this cohort will provide increased power to study these associations.

Ashkenazic (European Jewish) populations are at increased risk of particular cancers, such breast and ovarian cancers, due to mutations in BRCA1, BRCA2, BLM FANCC, and other genes involved in DNA repair; but only a third of our cohort originated in Europe. ${ }^{17}{ }^{18}$ Furthermore, genes that code for DNA repair are not known to contribute to pre-eclampsia. Other mutations in genes affecting thrombophilia or hyperhomocysteinaemia or those influencing angiogenesis and trophoblast invasion might be associated with both pre-eclampsia and cancer in our population. ${ }^{19}{ }^{20}$ We could not adjust for smoking history since data on this exposure were missing for about half the cohort. Nevertheless the finding of increased lung and larynx cancer among those with previous pre-eclampsia is intriguing given the purported protective effect of smoking in pre-eclampsia. ${ }^{1}$ On the other hand polymorphisms in the human epoxide hydrolase (a detoxifying enzyme) gene have been associated with both lung and larynx cancer as well as pre-eclampsia, ${ }^{21-23}$ providing a possible mechanism for this association. Evidence is emerging for differential effects of candidate genes in the pathogenesis of pre-eclampsia among different populations. ${ }^{24}$ Alternatively, diet (for example, folate intake), insulin resistance, smoking, or patterns of infection might represent common pathways in the pathogenesis of cancer and pre-eclampsia, and their effects might be expected to differ between populations.

We thank Lisa Deutsch for assistance in the statistical analysis.

Contributors: OP and SH were responsible for the conception and design of the study, analysis of the data, and the writing and revision of the manuscript; they will act as guarantors for the paper. YF participated in the design and analysis of the study and preparation of the final manuscript. ET and MB participated in data acquisition and preparation of the final manuscript. ET and XX participated in data analysis and approval of the final manuscript. OP, SH, and YF obtained funding.

Funding: This study was funded by the National Institutes of Health (RO1 CA80197).

Competing interests: None declared.

Ethical approval: The study was approved by the institutional review boards in the participating institutions and by Israel's ministries of health and the interior.

1 Odegard RA, Vatten LJ, Tore Nielsen S, Salvesen KA, Austgulen R. Risk factors and clinical manifestations of pre-eclampsia. Br J Obstet Gynaecol 2000;107:1410-6.

2 Irgens HU, Reisaeter L, Irgens LM, Lie RT. Long term mortality of mothers and fathers Irgens HU, Reisaeter L, Irgens LM, Lie RT. Long term mortality of mother
after preeclampsia: population based cohort study. BMJ 2001;323:1213-6.

3 Mogren I, Stenlund H, Högberg U. Long-term impact of reproductive factors on the risk of cervical, endometrial, ovarian and breast cancer. Acta Oncologica 2001;40:849-54. Cohn BA, Cirillo RM, Christianson RE, van den Berg BJ, Siiteri PK. Placental characteristics and reduced risk of maternal breast cancer.J Natl Cancer Inst 2001;93:1133-40. 5 Vatten LJ, Romundstad PR, Trichopoulos D, Skjaerven R. Pre-eclampsia in pregnancy and subsequent risk for breast cancer. BrJ Cancer 2002;87:971-3.

6 Polednak AP, Janerich DT. Characteristics of first pregnancy in relation to early breast cancer. A case-control study.J Reprod Med 1983;28:314-8.

Thompson W, Jacobson H, Negrini B, Janerich D. Hypertension, pregnancy, and risk of breast cancer. J Natl Cancer Inst 1989;81:1571-4.

8 Troisi R, Weiss H, Hoover RN, Potischman N, Swanson CA, Brogan DR, et al. Pregnancy characteristics and maternal risk of breast cancer. Epidemiology Pregnancy $1998 ; 9: 641-7$.

9 Innes KE, Byers TE. Preeclampsia and breast cancer risk. Epidemiology 1999;10:722-32.

10 Higgins JR, de Swiet M. Blood-pressure measurement and classification in pregnancy. Lancet 2001;357:131-5.

11 Davies AM, Prywes R, Tzur B, Wesikopf P, Sterk VV. The Jerusalem Perinatal Study. 1. Design and organization of a continuing, community-based, record linked survey. Isr J Med Sci 1969;5:1095-1106.

12 Steinitz R, Parkin DM, Young JL, Bieber CA, Katz L. Cancer incidence in Jewish migrants to Israel 1961-1981. Scientific Publication No 98 Lyon: World Health Organization, International Agency for Research on Cancer.

13 Israel Center for Disease Control. Investigation into the completeness of the Israel Cancer Registry. Methods and results. Publication 230. Israel Center for Disease Control, Oct 2003:31. (In Hebrew.)

14 Tamimi R, Lagiou P, Vatten LR, Mucci L, Trichopoulos D, Hellerstein S, et al. Pregnancy hormones, pre-eclampsia, and implications for breast cancer risk in the offspring. Can cer Epi Biomarkers Prev 2003;12:647-50.

15 Troisi R, Potischman N, Roberts JM, Ness R, Crombleholme W, Lykins D, et al. Maternal serum oestrogen and androgen concentrations in preeclamptic and uncomplicated pregnancies. Int J Epidemiol 2003;32:455-60.

16 Roberts JM, Cooper DW. Pathogenesis and genetics of pre-eclampsia. Lancet 2001;357:53-6.

17 Struewing JP, Abeliovich D, Peretz T, Avishai N, Kaback MM, Collins FS, et al. The carrier frequency of the BRCA1 185delAG mutation is approximately 1 percent in rier frequency of the BRCA1 185delAG mutation is a

18 Peleg L, Pesso R, Goldman B, Dotan K, Omer M, Friedman E, et al. Bloom syndrome and Fanconi's anemia: rate and ethnic origin of mutation carriers in Israel. Isr Med Assoc J 2002;4:95-7.

19 Pridjan G, Puschett JB. Preeclampsia. Part 2: experimental and genetic considerations. Obstet Gynecol Surv 2002;57:619-40.

20 Sherer DM, Abulafia O. Angiogenesis during implantation and placental and early embryonic development. Placenta 2001;22:1-13.

21 Zusterzeel P, Peters W, Visser W, Hermsen K, Roelofs H, Steegers E. A polymorphism in the gene for microsomal epoxide hydrolase is associated with preeclampsia. J Med Genet 2001;38:234-7.

22 Zhao H, Spitz MR, Gwyn KM, Wu X. Microsomal epoxide hydrolase polymorphisms and lung cancer risk in non-Hispanic whites. Mol Carcinog 2002;33:99-104.

23 Park JY, Schantz SP, Lazarus P. Epoxide hydrolase genotype and orolaryngeal cancer Park JY, Schantz SP, Lazarus P. Epoxide hydrolase genotype and or-
risk: interaction with GSTM1 genotype. Oral Oncol 2003;39:483-90.

24 Chikosi AB, Moodley J, Pegoraro RJ, Lanning PA, Rom L. 5,10 methylenetetrahydrofolate reductase polymorphism in black South African women with pre-eclampsia. $\mathrm{BrJ}$ Obstet Gynaecol 1999;106:1219-20.

(Accepted 21 January 2004)

doi 10.1136/bmj.38032.820451.7C

Braun School of Public Health and Community Medicine, Hadassah-Hebrew

University, Jerusalem 91120, Israel

Ora Paltiel senior lecturer

Yehiel Friedlander professor

Efrat Tiram doctoral candidate

Israel Cancer Registry, Ministry of Health, Jerusalem 91010, Israel

Micha Barchana director

Department of Epidemiology and Population Health, Albert Einstein College of Medicine of Yeshiva University, New York 10461, USA

Xiaonan Xue statistician

Department of Epidemiology, Mailman School of Public Health, Columbia

University, New York 10032, USA

Susan Harlap professor

Correspondence to: O Paltiel ora@vms.huji.ac.il 